\author{
JAROSŁAW STRÓŻYK \\ Instytut Studiów Międzynarodowych \\ Wydział Nauk Społecznych \\ Uniwersytet Wrocławski \\ ORCID 0000-0002-2379-9578 \\ jaroslaw.strozyk@uwr.edu.pl
}

\title{
Współpraca wojskowa NATO z państwami Kaukazu od 1991 roku
}

Drzwi otwarte czy uchylone?

\section{NATO Military Cooperation with the Caucasus states}

Fully or Slightly Open Door Policy

Słowa kluczowe:

NATO, Gruzja, Kaukaz,

Rosja, Armenia,

Azerbejdżan, członkostwo, partnerstwo
Keywords:

NATO, Georgia, Caucasus, Russia, Armenia, Azerbaijan, membership, partnership 


\section{NATO Military Cooperation with the Caucasus states. Fully or Slightly Open Door Policy}

NATO declares open door policy towards aspiring countries since 90s. States from South Caucasus region took the effort to adjust its defense and security systems to NAO standards. To become a fully-fledged NATO members the main obstacle remains the lack of political will to extend NATO commitment to collective defense. Additionally self-imposed limitations of some NATO members stemming form 1997 NATO-Russia Founding Act plays a vital role. It's hard to assume that new Strategic Concept will grant an automatic membership to any of NATO partner countries. Georgia, Armenia nor Azerbaijan have been seriously considered as NATO member states. The door are barely open. 
Degion Kaukazu jest istotnym obszarem z punktu widzenia bezpieczeńNstwa euroatlantyckiego, a ewentualne członkostwo Gruzji w NATO pozostaje przedmiotem dyskusji od ponad dwóch dekad. Celem artykułu jest odpowiedź na pytanie, jaki był i jaki jest obecnie rzeczywisty poziom współpracy wojskowej NATO z państwami regionu oraz otwartości tej organizacji na nowych członków. Podstawą źródłową analizy będą dokumenty Sojuszu Północnoatlantyckiego oraz materiały dotyczące współpracy członków NATO z państwami Kaukazu. Dobrym uzupełnieniem, pokazującym psychologiczną warstwę współpracy z partnerami są wspomnienia byłych wysokich urzędników państw członkowskich Sojuszu. Analiza pozwoli określić rzeczywisty stopień otwartości sojuszu na nowych członków z regionu. Zbadany także zostanie stopień zaangażowania Gruzji oraz Armenii i Azerbejdżanu w proces reformowania podsystemów: kierowania bezpieczeństwem narodowym, ochronnego oraz obronnego. Istotne w tym kontekście jest zbadanie działań Federacji Rosyjskiej, w tym dezinformacji, wobec szeroko rozumianej strefy jej wpływów. O ile przedmiotem badań są często uwarunkowania polityczne, o tyle ocena poziomu współpracy wojskowej jest traktowana pobieżnie. Sumarycznie głównymi kwantyfikatorami wagi strategicznej Kaukazu w zakresie rozszerzenia form i metod współpracy NATO z państwami tego regionu są ryzyko polityczno-wojskowe, a w tej przestrzeni relacje $\mathrm{z}$ Rosją oraz koszty finansowe.

\section{Partnerstwo różnych prędkości}

Sojusz Północnoatlantycki od lat 90. deklaruje politykę otwartych drzwi wobec państw aspirujących do NATO, a także politykę współpracy o różnym natężeniu z innymi partnerami. W praktyce Sojusz realizuje partnerstwo kilku prędkości. W pierwszej grupie znajdują się Szwecja i Finlandia. W nomenklaturze NATO, choć to państwa partnerskie, spełniają one wszystkie kryteria i mogą niemal natychmiast dołączyć do Sojuszu. Brak jest jednak woli politycznej rządów tych państw, które deklarują bezaliansowość. Ich współpraca z NATO, często określana partnerstwem specjalnym, ma w dużej mierze wymiar wojskowy poprzez aktywny udział w wielu operacjach wojskowych $\mathrm{NATO}^{1}$, w tym np. w Libii w marcu 2011 roku,

1 Oficerowie sił zbrojnych Finlandii i Szwecji uczestniczą w ćwiczeniach sztabowych NATO. Dla Sojuszu szczególnie cenne są np. zdolności rozpoznawcze Szwecji 
wymagających natychmiastowego użycia najnowocześniejszych samolotów bojowych i systemów rozpoznania ${ }^{2}$. Na drugim biegunie sytuują się państwa będące członkami specjalnych, regionalnych programów partnerskich, takich jak Dialog Śródziemnomorski (Mediterranean Dialogue, MD) czy Stambulska Inicjatywa Współpracy (Istanbul Cooperation Initiative, ICI). Te platformy służą głównie poprawie możliwości operacyjnych NATO w przypadku prowadzenia misji wojskowych w tych regionach. Są także narzędziem promocji Sojuszu Północnoatlantyckiego. Pozostałe zaś państwa partnerskie, w tym Armenia, Azerbejdżan i Gruzja, podążają utartą ścieżką dostosowywania podsystemów i oczekiwana na akceptację polityczną głównych rozgrrywających w NATO, wynikającą m.in. ze splotu wydarzeń międzynarodowych, szeroko otwierających drzwi dla nowych członków, tak jak na przełomie XX i XXI wieku.

Po 2014 roku, wraz z adaptacją Sojuszu Północnoatlantyckiego do nowych zagrożeń, w tym rosnącego rewanżyzmu Federacji Rosyjskiej, uwidoczniło się także nowe podejście NATO do programów partnerskich, które można nazwać próbą hybrydowego podejścia do partnerów. Tworzone są nowe formuły kooperacji przy wykorzystaniu dotychczasowych kanałów współdziałania. Należą do nich Platforma Interoperacyjności (Interoperability Platform - IP), która umożliwia prowadzenie konsultacji na różnych szczeblach dyplomatycznych i wojskowych. Przystąpiły do niej 23 państwa, od Australii, Nowej Zelandii, Japonii i Korei Płd. poprzez Kazachstan, Armenię, Azerbejdżan i Gruzję, państwa bliskowschodnie i regionu Sahelu po Serbię, Ukrainę, Finlandię i Szwecję ${ }^{3}$. Drugim formatem jest Partnerstwo Poszerzonych Możliwości (Enhanced Opportunity Partner - EOP). Program ten jest przyznany państwom najbardziej zaangażowanym w operacje wojskowe Sojuszu. W 2014 r. EOP został zaoferowany Australii, Finlandii, Gruzji, Jordanii i Szwecji, a w czerwcu 2020 r.

$\mathrm{w}$ zakresie rozpoznania elektromagnetycznego SIGINT (Signal Intelligence). Finlandia i Szwecja otworzyły także swoją przestrzeń powietrzną dla sojuszniczych samolotów ostrzegania z powietrza AWACS, ściśle współpracując w dziedzinie obrony powietrznej z Norwegią.

2 C. Huntington, Sweden and Finland's special relationship with NATO, Atlantic Forum, [dostęp: 20 VII 2021]: <https://atlantic-forum.com/content/sweden-and-finland $\% \mathrm{E} 2 \% 80 \% 99$ s-special-relationship-nato $>$.

3 Partnership Interoperability Initiative, NATO, 24 VIII 2021 [dostęp: 22 VII 2021]: 〈https://nato.int/cps/natohq/topics_132726.htm〉. 
do programu została włączona Ukraina. W ramach EOP prym wiodą cztery państwa (Gruzja, Ukraina, Szwecja, Finlandia), które przekazują wojska na potrzeby utrzymywanych $\mathrm{w}$ stałym pogotowiu wielonarodowych Sił Odpowiedzi NATO (NRF) ${ }^{4}$. Uzupełnieniem nowych platform współpracy jest Inicjatywa Wzmacniania Zdolności Obronnych (Defence and Related Security Capacity Building - DCB) zaoferowana dotychczas Gruzji, Jordanii i Mołdawii, Irakowi oraz Tunezji ${ }^{5}$.

\section{Obietnice NATO złożone Rosji}

W ocenie przedstawicieli środowiska politycznego i naukowego Federacji Rosyjskiej Sojusz Północnoatlantycki złamał obietnicę daną Kremlowi w 1990 roku nt. nierozszerzenia NATO o nowe państwa członkowskie byłych satelitów Moskwy ${ }^{6}-\mathrm{w}$ zamian za wycofanie żołnierzy rosyjskich z Niemiec ${ }^{7}$. Paradoksalnie obietnicę składano ZSRR, a w grupie siedmiu państw, które dołączyły do Sojuszu w 2004 roku, znalazły się trzy państwa, które jeszcze w 1990 roku były częścią ZSRR. W 2014 roku przypominał o niej Aleksander Łukin ${ }^{8}$. W jego ocenie dopiero prezydent Władimir Putin po objęciu prezydentury w 2000 roku rozpoczął negowanie tego rodzaju zachodniej narracji, a nowy rozdział stosunków Wschód-Zachód nastąpił wraz z aneksją Krymu i inwazją na Ukrainę. Kanonicznym wykładem takiego stanowiska Rosji i zapowiedzią wydarzeń w Gruzji i na Ukrainie było wystąpienie Putina w czasie dorocznej Konferencji Bezpieczeństwa w Monachium w 2007 roku. Według Marka Kramera z Uniwersytetu Harvarda zapewnienia o nierozszerzaniu Sojuszu to jeden z mitów okresu upadku muru berlińskiego ${ }^{9}$. Werbalne, a zatem niewiążące deklaracje

4 W. Lorenz, Ewolucja wspótpracy NATO z partnerami - szanse $i$ wyzwania, Biuletyn PISM nr 175(2107), 21 VIII 2020.

5 Defence and Related Security Capacity Building Initiative, NATO, 9 VI 2021 [dostęp: 22 VI 2021]: 〈https://www.nato.int/cps/en/natohq/topics_132756.htm〉.

6 M. E. Sarotte, A broken promise?, "Foreign Affairs" 2014, vol. 93, no 5, s. 90-97.

7 R. Kupiecki, NATO w polskiej perspektywie, PISM, Warszawa 2019, s. 35.

8 A. Łukin, What the Kremlin is thinking, Putin's vision for Eurasia, "Foreign Affairs", July/August 2014 .

9 M. Kramer, A myth of no-NATO Enlargement to Russia, "Washington Quaterly" 2009, 32/2, s. 39-61. 
dyplomatów amerykańskich, w tym te najdalej idące - o nierozszerzaniu NATO o wschodnią część zjednoczonych Niemiec - pojawiały się w czasie rozmów nt. zjednoczenia Niemiec w 1990 roku, lecz nigdy nie wyszły poza fazę wstępnej dyskusji ${ }^{10}$. Publiczne interpretacje zdarzeń z tamtego okresu ulegały zmianom $\mathrm{w}$ ostatnich 30 latach, a szczegółowe zmiany narracji w świetle istniejących dokumentów dyplomatycznych zostały dokładnie opisane $\mathrm{w}$ dostępnej literaturze ${ }^{11}$. Nie bez znaczenia są skuteczne rosyjskie kampanie dezinformacyjne i implementacja fałszywej polityki historycznej Federacji Rosyjskiej, również w ramach skutecznych działań w przestrzeni cybernetycznej społeczeństw państw zachodnich ${ }^{12}$. Element „oszustwa” NATO z ostatnich trzech dekad wpisuje się w narrację historyczną Putina, skierowaną na arenę wewnętrzną, pokazującą niewdzięczny Zachód, który chce zniszczyć Rosję, tak jak to zrobił ze Związkiem Radzieckim ${ }^{13}$, a także podkreślającą „historyczną sprawiedliwość” w postaci powrotu Półwyspu Krymskiego do macierzy rosyjskiej ${ }^{14}$.

\section{Geopolityka i geografia}

Geopolityka powraca w ostatnich latach do głównego nurtu dyskusji politycznych, akademickich oraz biznesowych porównywalnie do poziomu lat zimnowojennych. Ożywiona dyskusja jest efektem dostrzeżenia powrotu w polityce międzynarodowej do założeń realizmu, których część badaczy i publicystów nie zauważała w trakcie "końca historii” i swoistej pauzy strategicznej. Kształtowanie się nowych uwarunkowań geopolitycznych opartych na redefinicji roli USA i zdefiniowaniu miejsca Chin ma wpływ na pozostałe

10 Tamże.

11 Stosunki NATO-Federacja Rosyjska w świetle dokumentów, red. R. Kupiecki, M. Menkiszak), PISM, Warszawa 2018.

12 Operation "Secondary Infektion". A suspected Russian intelligence operation targeting Europe and the United States, Raport Atlantic Council's Digital Forensic Research Lab (DFRLab), 13 XI 2019: <https:/www.atlanticcouncil.org/wp-content/uploads/2019/o8/Operation-Secondary-Infektion_English.pdf> [dostęp: 20 VI 2021].

13 K. Stoner, Russia resurrected, 2020, s. 160-165.

14 J. Bornio, Bezpieczeństwo narodowe Polski w kontekście kryzysu ukraińskiego, Difin 2019, s. 236-237. 
regiony $^{15}$. Kaukaz to rejon strategiczny dla polityki energetycznej i gospodarki światowej. Szlaki komunikacyjne, które przechodzą przez terytorium Gruzji, Armenii i Azerbejdżanu, mają znaczenie globalne ${ }^{16}$. Upadek Związku Radzieckiego pozwolił na próby emancypacji regionu, zakończone częściowym sukcesem. Antagonizmy w regionie niezmiennie mają istotny potencjał konfliktogenny, w tym stanowią silne źródło wojny regionalnej w Górskim Karabachu. Nacjonalizmy i polityka Rosji są głównymi, lecz nie jedynymi czynnikami kształtującymi wewnętrzną scenę polityczną państw regionu. Osobnym zjawiskiem są zlokalizowane w Kaukazie Południowym trzy państwa samozwańcze, Abchazja, Osetia Południowa i Górski Karabach, nieuznawane przez społeczność międzynarodową ${ }^{17}$. Tereny Gruzji, Armenii i Azerbejdżanu określane są niekiedy mianem Zakaukazia, korytarza oddzielającego rejony kaukaskie od Turcji i Iranu.

Kaukaz Południowy obejmuje terytorium pomiędzy Morzem Czarnym a Kaspijskim zamieszkiwane przez ludność kilkudziesięciu narodowości. Jest istotnym węzłem transportowo-komunikacyjnym na pograniczu dwóch kontynentów: Azji i Europy, co określa jego położenie w kategoriach światowej gospodarki. Współczesne znaczenie Kaukazu Południowego podkreślają względy ekonomiczne, szczególnie te związane z wydobyciem, transportem i przesyłem surowców energetycznych. To główny powód, dla którego Rosja nie zamierza utracić swoich wpływów na tych terytoriach, a NATO nawiązuje sojusze polityczno-wojskowe. Należy pokreślić, iż państwa Kaukazu Południowego więcej dzieli, niż łączy, zarówno w domenie etniczno-kulturowej, jak i przede wszystkim w kwestii kierunków prowadzenia polityki zagranicznej. Gruzja jest prozachodnia, Armenia prorosyjska, Azerbejdżan natomiast może sobie pozwolić, z uwagi na posiadane zasoby naturalne, na prowadzenie zdywersyfikowanej polityki balansującej między Rosją i Turcją z udziałem innych państw, w tym USA. Liczba

15 A. Marc, B.Jones, The new geopolitics of state fragility, Brookings Institution, 3 II 2021 [dostęp: 12 VII 2021], <https://www.brookings.edu/blog/order-from-chaos/2021/o2/o3/ the-new-geopolitics-of-state-fragility/ $>$.

16 M. Bryza, The Greater Caspian region. A new Silk Road, with or without a new belt, Atlantic Council, 29 II 2020, [dostęp: 16 VI 2021]: 〈http://www.balochhouse. com/2020/o2/the-greater-caspian-region-new-silk.html $>$.

17 Z wyjątkiem Federacji Rosyjskiej, Nikaragui, Syrii i Wenezueli. 
sporów w regionie powoduje, iż nie ma ścisłej współpracy między państwami tam położonymi, chociażby z uwagi na konflikt o Górski Karabach czy kwestię Abchazji i Osetii. Łącznika nie stanowi też położenie geograficzne. Źródłem nieporozumień jest kultura i polityka, ale również etniczne pochodzenie, łączące $\mathrm{w}$ jednym regionie kilka odmiennych rodowo-plemiennych tradycji: kartwelską, abchasko-adygejską, nach-dagestańską, ałtajską, indoeuropejską i semicką ${ }^{18}$.

Jednym z najważniejszych wydarzeń na Kaukazie w XXI wieku, które zdefiniowało region, była agresja Rosji na Gruzję w 2008 roku. Objęcie w tym roku urzędu prezydenta Federacji Rosyjskiej przez Dmitrija Miedwiediewa dawało nadzieję na zmianę zachowania liderów i sposobu działania Rosji po agresywnych kadencjach Włądimira Putina ${ }^{19}$. Sukces Federacji Rosyjskiej w wojnie w Gruzji okazał się atutem rządzących Rosją wobec społeczności międzynarodowej, jak również ważnym wydarzeniem służącym narracji na użytek wewnętrzny. Polityka "dziel i rządź”, stosowana przez Rosję wobec NATO i Unii Europejskiej, była skuteczna już na wcześniejszym etapie niż aǵresja na Gruzję, tj. na Szczycie NATO w Bukareszcie w 2008 roku. Sprzeciw Rosji wobec zaproszenia do członkostwa w Sojuszu Północnoatlantyckim, choć nie mógł być skuteczny w sensie prawnym, bo formalnie Rosja nie ma prawa głosu decydującego w tej sprawie, to był skuteczny politycznie z uwagi na zachowanie części państw członkowskich $^{20}$. Francja i Niemcy przewodziły oponentom przyznania Planu Działań na rzecz Członkostwa (Membership Action Plan, MAP). Były szef polskiej dyplomacji, Radosław Sikorski, pisze wprost o obietnicy Niemiec złożonej Rosji, że nie udzielą zgody na objęcie MAP Ukrainy i Gruzji ${ }^{21}$. Wsparcia rządom francuskiemu oraz niemieckiemu udzieliły też Włochy, Węgry oraz państwa Beneluksu. Takiej koalicji nie mogły przeciwstawić się Stany Zjednoczone, orędownik kolejnego kroku Gruzji i Ukrainy na drodze do członkostwa w NATO $^{22}$.

18 A. Cucjev, Atlâs etnopolitičeskoj Kavkaza (1774-2004), Moskwa 2006, s. 7.

19 E. Lucas, Nowa zimna wojna, Dom Wydawniczy Rebus, Poznań 2008, s. 30.

20 Tamże, s. 31.

21 R. Sikorski, Polska może być lepsza, Znak Horyzont, Kraków 2018, s. 87.

22 S. Erlanger, S. Lee Myers, NATO Allies oppose Bush on Georgia and Ukraine, "New York Times" [online], 3 IV 2008 NATO Allies Oppose Bush on Georgia and Ukraine - The New York Times (nytimes.com)[dostęp: 20 VII 2021]. 


\section{NATO a Kaukaz}

Państwa Kaukazu nigdy nie były poważnie rozważane jako kandydaci na członków NATO. Dyskusje na temat członkostwa Gruzji w NATO co prawda były prowadzone jeszcze w latach 90. , lecz ich intensyfikacja nastąpiła w okresie 2004-2008. Duży wpływ na to miała prozachodnia administracja w Gruzji. Deklaracja przyszłego członkostwa Gruzji w Sojuszu, złożona w 2008 r. w Bukareszcie, nie precyzowała jednak ewentualnej perspektywy, a ponadto brak postępów w kolejnych latach powodował pogłębienie się stanu zamrożenia ${ }^{23}$. Doświadczenie Ukrainy i Gruzji z aspiracji do NATO pokazuje, że kierowanie współpracy z państwem partnerskim na biurokratyczne korytarze poprzez utworzenie komisji, komitetu lub grupy roboczej to odłożenie członkostwa w NATO ad calendas grecas. Komisja NATO-Gruzja powstała we wrześniu 2008 roku, w miesiąc po rosyjskiej agresji na to państwo, jest sztandarowym przykładem takiego działania. Państwa członkowskie kalkulują ryzyko polityczno-wojskowe, a w tej przestrzeni relacje $\mathrm{z}$ Rosją, koszty finansowe rozszerzenia oraz wagę strategiczną regionu Kaukazu. Te składowe skutkują w przypadku Gruzji oraz pozostałych państw regionu brakiem postępu w kwestii realnej perspektywy członkostwa w NATO.

Główną przeszkodą w realizacji rozszerzenia Sojuszu Północnoatlantyckiego o państwa Kaukazu jest brak woli politycznej państw NATo w kwestii rozszerzania zobowiązań dotyczących kolektywnej obrony. Dodatkowo istotne są zróżnicowane samoograniczenia państw NATO wynikające z Aktu Stanowiącego NATo-Rosja z 1997 roku. Dokument, który pozwolił dokonać pierwszej i drugiej fali rozszerzenia NATO w 1999 i 2004 roku, w tym o byłe republiki radzieckie - Estonię, Litwę i Łotwę - w dużej mierze zablokował starania innych państw byłego ZSRR lub w innym ujęciu stanowił pretekst do zaniechań ze strony państw członkowskich NATO. Ron Asmus, były wysoki urzędnik Departamentu Stanu USA, opisywał „kuchnię polityczną" z 1997 roku, w tym negocjacje z Rosją nt. Aktu Stanowiącego NATO-Rosja. Podkreślał przy tym szczególną rolę ówczesnej sekretarz stanu Madeleine Albright, a zwłaszcza jej osobiste doświadczenia rodzinne

23 M.Kubiak, Zamrożone partnerstwo: relacje Gruzja-NATO po szczycie w Brukseli, Warsaw Institute, 1 VIII 2018 [dostęp: 15 VII 2021]: <https://warsawinstitute.org/ $\mathrm{pl} /$ zamrozone-partnerstwo-relacje-gruzja-nato-po-szczycie-w-brukseli/ $>$. 
z okresu komunizmu (jest z pochodzenia Czeszką). W jego ocenie przełożyły się one w znaczącym stopniu na wolę polityczną USA i determinację w kwestii przyjęcia nowych państw członkowskich. Asmus określa to nawet jako imperatyw moralny Madeleine Albright ${ }^{24}$. Podsumowując postrzeganie zapisów porozumienia NATO-Rosja z 1997 roku, należy podkreślić, że aneksja Krymu i inwazja na Ukrainę jednoznacznie dezaktualizują zapisy dokumentu, które mówiły o "obecnych i dających się przewidzieć uwarunkowaniach bezpieczeństwa" Te z 2014 roku były już dalekie od zapisów z 1997 roku, stanowiły wręcz całkowicie nowe uwarunkowania bezpieczeństwa w obszarze odpowiedzialności Sojuszu Północnoatlantyckiego.

Priorytetem Sojuszu od początku kontaktów z państwami kaukaskimi była budowa zalążków integracji europejskiej regionu. NATO jest dla państw Kaukazu gwarantem w zakresie istotnych działań: reformy sił zbrojnych, ochrony rurociągów, rozwoju gospodarczego czy rozwiązywania konfliktów regiionalnych. Ważną częścią realizacji obietnic, a jednocześnie budowania nadziei NATO wobec państw Kaukazu, były wizyty sekretarzy generalnych tej organizacji, począwszy od Javiera Solany w 1997 roku. W praktyce każdy sekretarz NATO od tego czasu - George Robertson, Jaap de Hoop Scheffer, Anders Fogh Rassmussen oraz obecny Jens Stoltenberg - kontynuuje ten trend.

Mimo licznych inicjatyw występują zasadnicze różnice $\mathrm{w}$ indywidualnych relacjach między NATO a państwami Kaukazu Południowego, zarówno $\mathrm{w}$ formule współpracy organizacji z poszczególnymi państwami, jak i relacjach dwustronnych członków NATO z partnerami. Partnerstwo Sojuszu z państwami Kaukazu Południowego to jeden z wielu programów partnerskich NATO. Pierwsze relacje nawiązano w 1991 roku. Rok później rozpoczęła działanie Rada Współpracy Północnoatlantyckiej (North Atlantic Cooperation Council, NACC), a celem jej powstania było zacieśnienie kontaktów z członkami byłego Układu Warszawskiego. Choć państwa Kaukazu nie uczestniczyły $\mathrm{w}$ posiedzeniach inauguracyjnych, to dołączyły do składu NACC jeszcze w 1992 roku. Rozszerzenie współpracy między regionem a NATO nastąpiło po 1999 roku. Przełomowy w kształtowaniu wzajemnych stosunków między NATO a Kaukazem Południowym był szczyt NATO w Stambule w 2004 roku. Uznano wtedy region za priorytetowy w budowaniu korytarzy tranzytowych na Bliski Wschód w osi

24 R. Asmus, Opening NATO's door. How the Alliance remade itselffor a new era, Columbia University Press, New York, s. 176-190. 
północ-południe, a do Turcji i Azji Centralnej w osi wschód-zachód, również $\mathrm{z}$ uwagi na rozmieszczenie $\mathrm{w}$ tamtym regionie amerykańskich baz tranzytowych do Afganistanu.

Stany Zjednoczone w latach 90. traktowały Gruzję w sposób specjalny. Entuzjazm prezydenta Billa Clintona w kwestii rozszerzania NATO, jak pokazują archiwa z okresu jego prezydentury, obejmował także to państwo ${ }^{25}$. $\mathrm{Na}$ podstawie ocen politycznych i wojskowych Gruzja była traktowana jako prymus procesu akcesyjnego $\mathrm{w}$ tym regionie. Sprzyjało temu także duże poparcie społeczeństwa gruzińskiego (szczegóły w sekcji Gruziński lider). Interesującym elementem było gruzińskie pochodzenie najwyższego rangą amerykańskiego żołnierza, generała Johna Shalikashvili, przewodniczącego Połączonego Komitetu Szefów Sztabów Sił Zbrojnych USA w latach 1993-1997, za pierwszej kadencji Billa Clintona. Jego starszy brat, Otar Shalikashvili, był pułkownikiem SZ USA ${ }^{26}$, a po odejściu na emeryturę w 2001 roku został doradcą sekretarza obrony ds. Gruzji i był odpowiedzialny za amerykański program pomocy wojskowej, w tym specjalny obszerny program szkoleniowy (Georgia Train-and-Equip program, GTEP) ${ }^{27}$. Takie osobiste relacje i doświadczenia, podobnie jak w przypadku Madeleine Albright wobec państw Europy Środkowej w latach 90., mogły w niektórych przypadkach sprzyjać Gruzji w aspiracjach do NATO, lecz nie przełożyły się na poziom decyzji politycznej. Stany Zjednoczone wciąż traktują Gruzję jako lidera w regionie. W czerwcu 2021 roku Departament Stanu USA skierował do rządu w Tbilisi prośbę o podjęcie się roli mediatora między Armenią a Azerbejdżanem w rozwiązaniu sporów po wojnie o Górski Karabach z 2020 roku $^{28}$.

Sojusz Północnoatlantycki politycznie kontroluje stosunki z państwami Kaukazu poprzez specjalnego wysłannika sekretarza generalnego NATO

25 M. Mihkelson, Clinton archives confirm the need for NATO enlargement, International Centre for Defence and Security, 28 XI 2018 [dostęp: 16 VII 2021]: <https://icds.ee/ en/clinton-archives-confirm-the-need-for-nato-enlargement/ $>$.

26 John Shalikashvili i Otar Shalikashvili to synowie gruzińskiego dyplomaty, który opuścił Gruzję w 1921 roku, po zajęciu Gruzji przez Związek Radziecki. Zamieszkał w Warszawie, gdzie urodził się John. Otar urodził się w Milanówku.

27 Col. Otar Shalikashvili on details of the Train-and-Equip Program, Meetings Notes, Georgian Institute of Public Affairs, 15 V 2002 [dostęp 20 VII 2021]: <https://old. civil.ge/eng/article.php?id=1873>.

28 G. Menabde, US asks Georgia to mediate between Armenia and Azerbaijan, "Eurasia Daily Monitor" 2021 [online], vol. 18, issue 94, 14 VI 2021 [dostęp: 22 VII 021]. 
ds. Kaukazu i Azji. Rezyduje on jednak w Kwaterze Głównej NATO. Stanowisko zostało stworzone na podstawie decyzji szefów państw członkowskich podjętej w czasie Szczytu NATO w Stambule w 2004 roku $^{29}$. Współpracy Sojuszu z regionem powinna sprzyjać stabilizacja kadrowa na tym stanowisku. W ciągu siedemnastu lat obowiązki te wypełniały tylko dwie osoby: amerykański dyplomata Robert F. Simmons do 2010 roku i obecnie Kanadyjczyk James Appathurai, były rzecznik prasowy NATO. Doradza on przedstawicielem Armenii, Azerbejdżanu oraz Gruzji w procesie reform sektora bezpieczeństwa oraz wskazuje dostępne narzędzia, będące w dyspozycji NATO, pomocne w czasie implementacji tych zmian. Promuje także sam Sojusz Północnoatlantycki i kwestie bezpieczeństwa transatlantyckiego, również poprzez media oraz kontakty ze społeczeństwem obywatelskim.

W ostatnich latach coraz silniejszym graczem w regionie staje się Turcja, która dołączyła do wyścigu mocarstw o wpływy w polityce kaukaskiej. Jej celem jest także udział $\mathrm{w}$ rozbudowie infrastruktury i stworzenie siatki powiązań ekonomicznych. Turcja w praktyce nie uczestniczy w polityce partnerskiej NATO, a wszystkie projekty prowadzi samodzielnie. Zgodnie z inicjatywą „Azja od nowa” Turcja od 2019 roku realizuje szereg przedsięwzięć w regionie Kaukazu. Osią zaangażowania jest Azerbejdżan, z którym Ankara wzmacnia współpracę wojskową, w tym wywiadowczą. Finalnym punktem jest planowana budowa bazy wojskowej sił zbrojnych Turcji w Azerbejdżanie ${ }^{30}$. Zgodnie z założeniami ma to pozwolić na zastosowanie nowych środków wpływu i oddziaływania na Rosję, a także Iran i Armenię. Rosja dysponuje bazami wojskowymi w Armenii oraz Abchazji i Osetii Południowej.

Problemem w relacjach Armenia - Azerbejdżan pozostaje od ponad trzydziestu lat kwestia Górskiego Karabachu, czyli paradoksalnie - konflikt jeszcze sprzed powstania tych państw ${ }^{31}$. Jego geneza sięga przynajmniej przełomu XIX/XX wieku, później tlił się w krótkim okresie niepodległości i był pokłosiem włączenia Karabachu do Azerbejdżańskiej Socjalistycznej Republiki Radzieckiej w 1920 roku $^{32}$. Sojusz Północnoatlantycki nie uczest-

29 NATO Secretary General's Special Representative for the Caucasus and Central Asia, NATO, [dostęp: 2 VII 2021]: 〈https://www.nato.int/cps/en/natohq/topics_50101.htm>.

30 A. Legieć, Perspektywy polityki Turcji wobec Kaukazu Południowego, Biuletyn PISM nr 59/2257, 18 III 2021.

31 Ormiańska enklawa na obszarze Azerbejdżanu, która w 1991 r. ogłosiła niepodległość.

32 K. Strachota, Konflikty zbrojne na obszarze postradzieckim. Stan obecny, perspektywy uregulowania. OSW, 10 VI 2003. 
niczy w negocjacjach pokojowych dotyczących Górskiego Karabachu, które są realizowane w ramach tzw. Grupy Mińskiej Organizacji Bezpieczeństwa i Współpracy w Europie (OBWE). NATO zachęca wszystkie strony do pokojowego rozwiązania problemu. Konflikt między Armenią i Azerbejdżanem o Górski Karabach mógłby się wydawać dość odległy i abstrakcyjny z punktu widzenia bezpieczeństwa transatlantyckiego, ale wbrew pozorom taki nie jest. Wszystko przez to, że antagoniści w tym sporze mają sojuszników - Rosję (Armenia) i Turcję (Azerbejdżan). To sprawia, że kwestie te nabierają szerszego wymiaru. Turcja od początku dość zdecydowanie i aktywnie popiera działania Azerbejdżanu. W czasie kinetycznej fazy ostatniej odsłony konfliktu o Górski Karabach w 2020 roku prezydent Turcji Recep Tayyip Erdoğan jednoznacznie twierdził, że Azerowie "musieli wziąć sprawy we własne ręce” wobec okupowania części ich terytorium przez Ormian i wezwał Armenię do „opuszczenia okupowanego terytorium". Postawa Turcji wobec Armenii jest jednym ze źródeł napięć z Francją, co przekłada się bezpośrednio na relacje w NATO ${ }^{33}$.

\section{Gruziński lider, balans Armenia-Azerbejdżan}

NATO dzieli współpracujące $\mathrm{z}$ nim państwa Kaukazu na dwie grupy. Do pierwszej z nich należy zaliczyć Gruzję, a do drugiej Armenię i Azerbejdżan, które NATO w praktyce traktuje jednakowo, chcąc zachować poprawność polityczną i balans między zwaśnionymi stronami.

Gruzja intensywnie reformuje i profesjonalizuje swoje siły zbrojne oraz inne struktury państwowe, a członkostwo w NATO cieszy się poparciem miejscowej opinii publicznej. Aprobata społeczeństwa gruzińskiego dla członkostwa w NATO, jak również w Unii Europejskiej, od wielu lat utrzymuje się na bardzo wysokim poziomie, a nawet bywa wyższa niż w państwach członkowskich NATO. Według badań National Democratic Institute prowadzonych w ostatniej dekadzie oscyluje ono w okolicach $70 \%$. Najniższe poparcie dla członkostwa w NATO odnotowano w 2016 roku na poziomie $61 \%$, najwyższe - w 2012 roku - 81\%. W 2020 roku wyniosło ono $74 \%$. Dane dotyczące poparcia dla wstąpienia do Unii Europejskiej wynosiły odpowiednio: najwyższe - 83\% w 2018 roku, najniższe - 61\%

33 W. Górecki, M. Chudziak, The (pan-)Turkic Caucasus. The Baku-Ankara alliance and its regional importance, osw Commentary No 374, 1 II 2021. 
w 2015 roku. W 2020 roku z kolei było ono zbliżone do najwyższego i wynosiło $82 \%{ }^{34}$.

Gruzja od trzech dekad w sposób szczególnie bliski współpracuje z Sojuszem, uczestnicząc m.in. licznym kontyngentem wojskowym w operacji NATO w Afganistanie. W szczytowym okresie zaangażowania w operację ISAF kontyngent gruziński liczył 1500 żołnierzy, co stanowiło piąty pod wzǵlędem liczebności kontyngent w Afganistanie ${ }^{35}$. Wyszkolone w USA jednostki wojskowe uczestniczyły w najbardziej skomplikowanych działaniach bojowych operacji ISAF. Poniosły także dotkliwe straty. Trzydziestu dwóch żołnierzy gruzińskich zǵinęło w Afganistanie, co przy liczbie wysłanych żołnierzy plasowało to państwo na drugim miejscu po Danii pośród wszystkich uczestników operacji ISAF. Szczególne relacje łączące NATO z Gruzją, w porównaniu z Armenią i Azerbejdżanem, pokazuje utworzenie bezpośrednio w Tbilisi Biura Łącznikowego NATO. Na tle podobnych komórek sojuszniczych w innych państwach partnerskich to dosyć duże, czternastoosobowe, biuro, które pozwala na codzienne kontakty i praktyczny dialog na linii Bruksela-Tbilisi, realizowany na podstawie Planu Rocznej Współpracy (Annual National Plan, ANP). Priorytety biura nie wykraczają jednak poza wymieniane każdorazowo przy opisywaniu współpracy NATO-Gruzja wzmacnianie procesu reform i integracji oraz dialogu politycznego, a także wspierania transformacji i demokratycznego nadzoru nad sektorem bezpieczeństwa.

Sojusz Północnoatlantycki wspiera Gruzję także poprzez specjalny fundusz NATO Trust Fund wykorzystywany do finansowania szkoleń saperskich oraz oczyszczenia składów amunicji w miejscowości Skra. Projektem o wartości 1,35 mln Euro zarządzały wspólnie Litwa i Czechy. Wsparciem po agresji Rosji na Gruzję w 2008 roku jest także program rozwoju kadrowego Professional Development Programme (PDP), zapoczątkowany w 2009 roku. $\mathrm{W}$ jego ramach szkoleni są pracownicy administracji rządowej.

Współpraca NATO z Gruzją to w ostatniej dekadzie jednak stagnacja, bez realnych perspektyw na członkostwo w Sojuszu ${ }^{36}$. Po agresji Rosji

34 NDI poll: $82 \%$ of Georgians support EU, 74\%- NATO membership, Agenda.ge, 16 I 2020 [dostęp: 20 VII 2021] 〈https://agenda.ge/en/news/2020/146>

35 Georgia: now the top non-NATO troop contributor in Afghanistan, 26 VI 2013 [dostęp: 15 VI 2021]: 〈https://www.nato.int/cps/en/natolive/news_101633.htm>.

36 G. Menabde, NATO-Georgia: A pause in the integration process?, "Eurasia Daily Monitor", vol. 18, issue 109, 9 VII 2021. 
na Ukrainę Sojusz skoncentrował się na wzmocnieniu swojej wschodniej rubieży. Komisja NATO-Gruzja spotyka się cyklicznie (raz na kilka miesięcy), omawiając roczne plany współpracy oraz wymienione powyżej programy. Zastój $\mathrm{w}$ relacjach wynika $\mathrm{w}$ dużej mierze $\mathrm{z}$ pewnego kryzysu politycznego i społecznego w Gruzji, spowodowanego m.in. problemami gospodarczymi $^{37}$. Trudno utrzymać tak duży stopień politycznego poparcia przez trzy dekady ${ }^{38}$, nawet pomimo utrzymującej się w sondażach wysokiej aprobaty społecznej. Pogarsza się także sytuacja w otoczeniu Gruzji. Do negatywnej percepcji regionu przyczyniły się m.in. kinetyczna faza konfliktu w Górskim Karabachu w 2020 roku oraz głębsza współpraca Turcji z Rosją. Pomimo tego Gruzja wykonała poważne kroki w integracji z Zachodem, podpisując w czerwcu 2014 roku umowę stowarzyszeniową z Unią Europejską oraz zawierając w 2020 roku porozumienie z Joint Force Training Centre z Bydgoszczy, dotyczące utworzenia w Krtsanisi Ośrodka Szkoleniowego NATO-Georgia Joint Training and Evaluation Centre ${ }^{39}$. Szczególnie otwarcie nowej instytucji Sojuszu Północnoatlantyckiego, będące konsekwencją decyzji ze Szczytu NATO w Walii w 2014 roku w ramach pakietu NATOGruzja (Substantial NATO-Georgia Package, SNGP), jest istotnym krokiem budowy architektury bezpieczeństwa w regionie Kaukazu. SNGP był częścią inicjatywy NATo's Defense and Related Security Capacity Building Initiative (DCB), co oznacza, że Gruzja stała się częścią planu poprawy zdolności obronnych NATO. SNGP to dosyć obszerny program wsparcia w piętnastu obszarach, w tym $\mathrm{w}$ zakresie budowy ośrodka treningowego JTEC i szkoły dla pracowników administracji państwowej Defense Institutional Building School (DIBS), logistyki, wymiany informacji wywiadowczych, bezpiecznej łączności, lotnictwa, obrony przeciwlotniczej, sił specjalnych, żandarmerii, systemu pozyskiwania uzbrojenia, bezpieczeństwa morskiego,

37 Z. Anjaparidze, Can Russia capitalize on the current political unrest in Georgia?, "Eurasia Daily Monitor" [online], vol. 18, issue 38, , 8 III 2021 [dostęp: 23 VII 2021].

38 M. Falkowski, Gruziński dryf, Kryzys gruzińskiej drogi na Zachód, osw, Punkt widzenia nr 57, luty 2016.

39 Another milestone in NATO-Georgia cooperation. NATO Joint Force Training Centre and NATO-Georgia Joint Training and Evaluation Centre sign Partnership Agreement, 11 XII 2020 [dostęp: 23 VII 2021]: <https://www.jftc.nato.int/articles/ jftc-jtec-sign-partnership $>$. 
cyberbezpieczeństwa, komunikacji strategicznej, zarządzania kryzysowego oraz planowania strategicznego i operacyjnego.

W 2021 roku wciąż dominują medialne aspekty współpracy Gruzji z NATO. Wizyta specjalnego wysłannika Jamesa Appathuraia w lipcu 2021 roku, choć jak zawsze $\mathrm{z}$ fanfarami powitań i kolejnym orderem dla tego specjalnego wysłannika sekretarza generalnego, pokazała zastój w bilateralnych relacjach. Komunikat ze szczytu NATO w czerwcu 2021 roku także nie wykroczył poza zapewnienie, że deklaracja Sojuszu ze szczytu NATO w Bukareszcie w 2008 roku o członkostwie Gruzji w Sojuszu jest wciąż obowiązująca ${ }^{40}$. Według Vahtanga Maisaia w praktyce Gruzja pozostaje na trzecim z pięciu poziomów współpracy z Sojuszem, czyli realizuje intensywny dialog ${ }^{41}$. Przejście do czwartego, czyli planu współpracy członkowskiej (Membership Action Plan, MAP), jest kwestią decyzji politycznej i stanowiłoby rzeczywistą obietnicę członkostwa w NATO.W ocenie profesora Tornike Sharashenidze Gruzja wypełnia plan lepiej niż inne państwa aspirujące do Sojuszu, lecz obecna administracja amerykańska nie podejmie decyzji o przyznaniu Gruzji MAP z obawy przed eskalacją napięcia z Rosją ${ }^{42}$. Jednocześnie Sharashenidze twierdzi, że Gruzja może liczyć na pewnego rodzaju gwarancje bezpieczeństwa NATO, a budowane przez rząd w Tbilisi relacje z Turcją, Polską oraz Litwą, Łotwą i Estonią pomagają tworzyć parasol ochronny Sojuszu.

Pozytywnym przykładem zaangażowania wojskowego NATO była wizyta brytyjskiego okrętu w porcie w Batumi w czerwcu 2021 roku. HMS Defender wpłynął do gruzińskiego portu po incydencie z okrętami i samolotami rosyjskimi w pobliżu Półwyspu Krymskiego, a brytyjska załoga była witana $\mathrm{w}$ gruzińskim porcie jak bohaterowie ${ }^{43}$. Okręt następnie uczestni-

40 NATo Communique, szczyt NATO w czerwcu 2021 roku: "We reiterate the decision made at the 2008 Bucharest Summit, that Georgia will become a member of the Alliance with the Membership Action Plan (MAP) as an integral part of the process; we reaffirm all elements of that decision, as well as subsequent decisions, including that each partner will be judged on its own merit.".

41 G. Menabde, NATO-Georgia: A pause in the integration process?, "Eurasia Daily Monitor", vol. 18, issue 109, 9 VII 2021

42 Tamże.

43 Dwa okręty i dwadzieścia samolotów rosyjskich podążało za HMs Defender idącym kursem z Odessy wzdłuż Półwyspu Krymskiego, około 12 mil morskich (19 km) od wybrzeża. Jednostki rosyjskie wykonywały agresywne manewry, z okrętów 
czył w ćwiczeniach morskich z okrętami gruzińskiej Straży Wybrzeża. Siły morskie Gruzji zostały całkowicie zniszczone w czasie wojny w 2008 roku. Po odbudowanie wyposażenia swoją gotowość operacyjną odtwarzają w czasie dorocznych ćwiczeń morskich NATO pod kryptonimem "Sea Breeze” na Morzu Czarnym.

Ćwiczenia w Gruzji w wielu przypadkach na początku XXI wieku miały bardziej wymiar bilateralny z wojskami USA, jednakże od pięciu lat ćwiczenia odbywają w ramach NATO. Jednym z ważniejszych ćwiczeń z uwagi na jego wymiar logistyczny jest coroczne wydarzenie pod kryptonimem "Noble Partner". Pododdziały z państw NATO i ciężki sprzęt wojskowy docierają do Gruzji drogą lotniczą i morską. W czasie ćwiczeń w 2021 roku w czarnomorskim porcie Poti zacumował amerykański okręt Ocean Freedom. Oprócz gruzińskiej armii w ćwiczeniach po raz pierwszy wzięły udział jednocześnie jednostki m.in. z Polski, Stanów Zjednoczonych, Wielkiej Brytanii i Francji.

Azerbejdżan rozpoczął współpracę z NATO w 1992 roku, wstępując do Rady Współpracy Północnoatlantyckiej (North Atlantic Cooperation Council), pierwszego forum współpracy z państwami partnerskimi. Ta forma dialogu została zastąpiona w 1997 roku przez Euroatlantycką Radę Partnerstwa (Euro-Atlantic Partnership Council). Bardziej wymiernym w wymiarze wojskowym było dołączenie do programu Partnerstwa dla Pokoju (Partnership for Peace, PfP) w 1994 roku, tj. w momencie jego utworzenia. W programie PfP ważnym elementem był udział w Procesie Planowania i Oceny (PfP Planning and Review Process, PARP), który pozwalał ocenić potencjał danego partnera i zaplanować rozwój sił zbrojnych. To był istotny etap dla wielu państw, dający możliwość rozpoczęcia realnej współpracy z NATO. Duża część państw aspirujących w latach 90. dołączyła do Sojuszu Północnoatlantyckiego, ale kilka państw, w tym Azerbejdżan, wciąż pozostaje $\mathrm{w}$ fazie partnerskiej bez realnych perspektyw na przejście do kolejnego etapu ${ }^{44}$.

Współdziałanie Azerbejdżanu jest obecnie realizowane poprzez Indywidualny Plan Współpracy - Individual Partnership Action Plan (IPAP). W jego ramach uzgadniane i realizowane są w cyklu rocznym

padły strzały ostrzegawcze, a samoloty zrzuciły bomby na kursie brytyjskiego okrętu. Pomimo żądań Rosjan HMS Defender nie zmienił kursu.

44 Relations with Azerbaijan, NATO, [dostęp 28 VI 2021]: <https://www.nato.int/cps/ en/natohq/topics_49111.htm>. 
plany współdziałania z NATO oraz reformowania SZ Azerbejdżanu. Dodatkowo, Azerbejdżan stosunkowo aktywnie uczestniczy w różnych programach Sojuszu dedykowanych partnerom, zwiększającym ich zdolności bojowe, przygotowanie do zarządzania kryzysami, a także poprawę potencjału naukowego. Siły Zbrojne Azerbejdżanu uczestniczyły w operacjach NATO: KFOR w Kosowie od początku w 1999 roku do jej zakończenia w 2008 roku, oraz ISAF i późniejszej Resolute Support Mission (RSM) w Afganistanie. W szerszym kontekście Azerbejdżan uczestniczy w ćwiczeniach zarządzania kryzysowego NATO-wskiego Euro-Atlantic Disaster Response Coordination Centre (EADRCC) oraz mniej znanym programie NATO Science for Peace and Security Programme (SPS), który wspomaga naukowców. Azerbejdżan korzysta także z funduszy Sojuszu w kwestii rozminowywania kraju. Dotychczas udało się usunąć 640 tys. niewybuchów postsowieckich.

Azerbejdżan jest traktowany przez USA i Rosję jako dogodne, relatywnie neutralne miejsce spotkań amerykańsko-rosyjskich. Szef Sztabu Generalnego FR, gen. Walerij Gierasimow, wiele razy spotykał się tam z dowódcą wojsk USA w Europie, a jednocześnie dowódcą Sojuszniczego Dowództwa Operacyjnego NATO, gen. Todem Woltersem. W ocenie Hikmeta Hajiyeva, doradcy prezydenta Azerbejdżanu ds. współpracy międzynarodowej, oznacza to, że Azerbejdżan prowadzi niezależną politykę zagraniczną, ma bardzo dobre relacje strategiczne z Rosją, ale jednocześnie bardzo dobre stosunki z NATO w ramach programu Partnerstwo dla Pokoju. Według Hajiyewa Baku udostępnia swoim partnerom placówkę, gdzie wszystkie strony czują się komfortowo ${ }^{45}$, co jest raczej zbyt optymistyczną oceną pragmatycznego podejścia USA do miejsca rozmów z Rosją, które jest pochodną decyzji obu zaangażowanych podmiotów.

Armenia w praktyce realizuje współpracę z NATO w bliźniaczym rytmie z Azerbejdżanem. Dzieje się tak głównie z powodu woli NATO zachowania balansu pomiędzy zwaśnionymi stronami. W tych samych latach dołączyła do Rady Współpracy Północnoatlantyckiej, a następnie w 1997 roku do sukcesora NACC, Euroatlantyckiej Rady Partnerstwa, Partnerstwa dla Pokoju oraz Procesu Przeglądu i Oceny. W tamtym okresie Sojusz zaproponował nowym partnerom konsultacje polityczne, $\mathrm{w}$ tym $\mathrm{w}$ sprawach realizacji [online], 10 II 2020, [dostęp 22 VI 2021]. 
porozumień o kontroli zbrojeń i planowania oraz współpracę w zakresie operacji pokojowych, gospodarki, systemów informatycznych, konwersji przemysłu zbrojeniowego, nauki i techniki, przejrzystości budżetów wojskowych oraz demokratycznej kontroli sił zbrojnych. Armenia realizuje Indywidualny Plan Współpracy (Individual Partnership Action Plan, IPAP) ${ }^{46}$. W 2008 Armenia dołączyła do programu NATO dotyczącego poprawy szkolnictwa wojskowego Defence Education Enhancement Programme (DEEP).

Armenia stosunkowo aktywnie uczestniczy w różnych partnerskich programach pomocowych Sojuszu dedykowanych poprawie zdolności sektora obronnego. Siły zbrojne Armenii brały udział w misjach NATO w Kosowie praz Afganistanie. W Kosowie były one obecne od początku misji KFOR w 1999 roku do jej zakończenia w 2008 roku, podobnie jak w afgańskiej ISAF do 2011 roku i późniejszej Resolute Support Mission (RSM) w Afganistanie. Armenia uczestniczy w ćwiczeniach zarządzania kryzysowego NATO-wskiego Euro-Atlantic Disaster Response Coordination Centre (EADRCC) oraz NATO Science for Peace and Security (SPS) Programme.

Wymienione liczne formuły współpracy państw Kaukazu z NATO służą w dużej mierze wydłużaniu obietnicy członkostwa w Sojuszu bez wskazania realnego terminu decyzji politycznej NATO. Jednocześnie formalne zmiany terminologii grup i komitetów, jak również coroczne ogłaszanie zatwierdzonych planów pozwalają wykorzystywać to na wewnętrznej scenie politycznej Armenii, Azerbejdżanu oraz Gruzji do prezentowania rządów tych państw jako otwartych na kooperację z najskuteczniejszą międzynarodową organizacją międzynarodową.

\section{Partnerzy czy członkowie? Quo vadis NATO?}

Ostatnie trzydzieści lat funkcjonowania Sojuszu Północnoatlantyckiego to złoty okres dla państw aspirujących do NATO oraz wszelkich form partnerstwa. Od 1999 roku do szesnastu członków dołączyło kolejnych czternaście państw. W praktyce wszystkie operacje wojskowe tej organizacji w tym okresie odbywały się z udziałem partnerów. Z poziomu wizerunkowego oraz w mniejszym zakresie strategicznego trudno sobie wyobrazić kolejne misje bez ich partycypacji.

46 Zasady tego aspektu współpracy z NATO opisane zostały w kontekście Azerbejdżanu. 
NATO znajduje się w fazie permanentnej dyskusji o własnej przyszłości. Przy rosnącej liczbie wyzwań i zagrożeń zewnętrznych oraz zmieniającym się ich charakterze, odmiennych narodowych interesach oraz zwiększonej polaryzacji w polityce wewnętrznej, państwom członkowskim coraz trudniej jest znaleźć wspólny mianownik w kwestii przyjęcia nowych członków, zwłaszcza tych z Kaukazu, regionu o skomplikowanej lokalizacji geostrategicznej. Należy założyć, że opracowywana obecnie nowa koncepcja strategiczna NATO, mająca zastąpić tę z 2010 roku, nie stworzy podstaw do automatycznego otwarcia drzwi do NATO dla Kaukazu. Nie taka jest rola tego dokumentu. Wciąż będą istniały różnice między państwami członkowskimi w podejściu do wyzwań i zagrożeń ${ }^{47}$. Sojusz Północnoatlantycki, poza okresem zimnej wojny, nigdy nie miał rzeczywistej, wspólnej i podzielanej przez wszystkich członków oceny zagrożeń. Dyskusja o przyszłości NATO ma wpływ na współpracę z Kaukazem. Państwa tego regionu mogą także stanowić pomost dla NATO w kierunku Chin, priorytetu USA na najbliższe dekady. Stany Zjednoczone przygotowują zaplecze logistyczne ewentualnych operacji Dowództwa Indo-Pacyfiku, a Kaukaz może być dobrym punktem przeładunkowym i bazą lotniczą.

Państwa Kaukazu reformują swój system obronny, tak aby sprostać wymaganiom prawnym oraz sprawdzonym i skutecznym $\mathrm{w}$ operacjach bojowych standardom wojskowym NATO. To złożona procedura dostosowania systemu bezpieczeństwa państwa, w tym np. ochrony informacji niejawnych, do standardów Sojuszu Północnoatlantyckiego. Siły Zbrojne każdego nowego członka NATO muszą uzyskać określony stopień kompatybilności z jednostkami obecnych sojuszników. Systemy łączności to podstawa współdziałania w czasie wspólnych operacji wojskowych.

NATO uznaje aspiracje Gruzji do członkostwa, lecz wciąż będzie wstrzymywać się z przyznaniem jej oficjalnego statusu kandydata i udziału w Planie Działań na rzecz Członkostwa MAP.W to miejsce w dającej się przewidzieć perspektywie czasowej będzie trwała quasi-współpraca w ramach Komisji NATO-Gruzja powołanej po wojnie z Rosją we wrześniu 2008 roku. Armenia i Azerbejdżan będą wciąż uczestniczyły w licznych programach oferowanych przez Sojusz Północnoatlantycki. Drzwi do NATO dla państw Kaukazu są jedynie uchylone.

47 W. Lorenz, NATO na drodze do nowej strategiii, Biuletyn PISM, nr 8/2206, 19 I 2021. 
Współpraca wojskowa NATO z państwami Kaukazu od 1991 roku. Drzwi otwarte czy uchylone?

\section{Bibliografia}

\section{Monografie}

Asmus R., Opening NATO's door. How the Alliance remade itself for a new era, Columbia University Press, New York, s. 176-190.

Bornio J., Bezpieczeństwo narodowe Polski w kontekście kryzysu ukraińskiego, Difin 2019, s. 236-237.

Cucjev A., Atlâs etnopolitičeskoj Kavkaza (1774-2004), Moskwa 2006, s. 7.

Kupiecki R., NATO w polskiej perspektywie, PISM, Warszawa 2019, s. 35.

Lucas E., Nowa zimna wojna, Dom Wydawniczy Rebus, Poznań 2008, s. 30.

Sikorski R., Polska może być lepsza, Znak Horyzont, Kraków 2018, s. 87.

Stoner K., Russia resurrected, 2020, s. 160-165.

Teksty opublikowane w ramach serii

Falkowski M., Gruziński dryf, Kryzys gruzińskiej drogii na Zachód, osw (Punkt widzenia, 57), luty 2016.

W. Górecki, M. Chudziak, The (pan-)Turkic Caucasus. The Baku-Ankara alliance and its regional importance, OSW (Commentary, 374), 1 II 2021.

Legieć A., Perspektywy polityki Turcji wobec Kaukazu Południowego, PISM (Biuletyn PISM nr 59/2257), 18 III 2021.

Lorenz W., Ewolucja wspótpracy NATO z partnerami - szanse $i$ wyzwania, Biuletyn PISM nr 175 (2107), 21VIII 2020.

Lorenz W., NATO na drodze do nowej strategii, Biuletyn PISM, nr 8 (2206), 19 I 2021.

Menabde G., NATO-Georgia: A pause in the integration process?, "Eurasia Daily Monitor", vol. 18, issue 109, 9 VII 2021.

Sarotte M. E., A broken promise?, "Foreign Affairs” 2014, vol. 93, no. 5, s. 90-97.

Stosunki NATO-Federacja Rosyjska $w$ świetle dokumentów, red. R. Kupiecki, M. Menkiszak, PISM, Warszawa 2018.

Strachota K., Konflikty zbrojne na obszarze postradzieckim. Stan obecny, perspektywy ureǵulowania. OSW, 10 VI 2003.

Artykuły w czasopismach

Kramer M., A myth of no-NATO enlargement to Russia, "Washington Quaterly" 2009, 32/2, s. 39-61.

Łukin A., What the Kremlin is thinking, Putin's vision for Eurasia, "Foreign Affairs", July/August 2014.

Internet

Anjaparidze Z., Can Russia capitalize on the current political unrest in Georgia?, "Eurasia Daily Monitor" [online], vol. 18, issue 38, o8 III 2021 [dostęp: 23 VII 2021].

Another milestone in NATO-Georgia cooperation. NATO Joint Force Training Centre and NATO-Georgia Joint Training and Evaluation Centre sign Partnership Agreement, 11 XII 2020 [dostęp: 23 VII 2021]: <https://www.jftc. nato.int/articles/jftc-jtec-sign-partnership $>$. 
Bryza M., The Greater Caspian region. A new Silk Road, with or without a new belt, Atlantic Council, 29 II 2020 [dostęp: 16 VI 2021]: 〈http://www.balochhouse. com/2020/o2/the-greater-caspian-region-new-silk.html $\rangle$.

Col. Otar Shalikashvili on details of the Train-and-Equip Program, Meetings Notes, Georgian Institute of Public Affairs, 15 V 2020 [dostęp: 20 VII 2021] <https:// old.civil.ge/eng/article.php?id=1873>.

Defence and Related Security Capacity Building Initiative, NATO, 9 VI 2021 [dostęp: 22 VI 2021]: 〈https://www.nato.int/cps/en/natohq/topics_132756.htm>. Erlanger S., Lee Myers S., NATO Allies Oppose Bush on Georgia and Ukraine, "New York Times" [online], 03.04.2008, [dostęp: 20 VII 2021].

Georgia: now the top non-NATO troop contributor in Afghanistan, NATO, 26 VI 2013 [dostęp: 15 VI 2021]: 〈https://www.nato.int/cps/en/natolive/news_101633.htm>. NATO Allies Oppose Bush on Georgia and Ukraine - The New York Times (nytimes.com)

Huntington C., Sweden and Finland's special relationship with NATO, Atlantic Forum, [dostęp: 20 VII 2021]: 〈https://atlantic-forum.com/content/sweden-andfinland $\% \mathrm{E} 2 \% 80 \% 99$ s-special-relationship-nato $>$.

Kubiak M., Zamrożone partnerstwo: relacje Gruzja-NATO po szczycie w Brukseli, Warsaw Institute, 1 VIII 2018 [dostęp: 15 VII 2021]: <https://warsawinstitute. org/pl/zamrozone-partnerstwo-relacje-gruzja-nato-po-szczycie-w-brukseli/>.

Marc A., Jones B., The new geopolitics of state fragility, Brookings Institution, 3 II 2021 [dostęp: 12 VII 2021] <https://www.brookings.edu/blog/order-from-chaos/ 2021/o2/o3/the-new-geopolitics-of-state-fragility/>.

Menabde G., US Asks Georgia to mediate between Armenia and Azerbaijan, "Eurasia Daily Monitor" [online], vol. 18, issue 94, , 14 VI 2021 [dostęp: 20 VII 2021].

Mihkelson M., Clinton archives confirm the need for NATO enlargement, International Centre for Defence and Security, 28 XI 2018 [dostęp: 16 VII 2021]: <https://icds. ee/en/clinton-archives-confirm-the-need-for-nato-enlargement/ $>$.

NATO Secretary General's Special Representative for the Caucasus and Central Asia, NATO, [dostęp: 2 VII 2021]: 〈https://www.nato.int/cps/en/natohq/topics_50101.htm〉.

NDI poll: $82 \%$ of Georgians support EU, 74\%- NATO membership, Agenda.ge, 16 I 2020 [dostęp: 20 VII 2021] 〈https://agenda.ge/en/news/2020/146>.

Operation "Secondary Infektion". A suspected Russian intelligence operation targeting Europe and the United States, Raport Atlantic Council's Digital Forensic Research Lab (DFRLab), 13 XI 2019: <https://www.atlanticcouncil.org/wp-content/uploads/2019/o8/Operation-Secondary-Infektion_English.pdf > [dostęp: 20 VI 2021].

Partnership Interoperability Initiative, NATO, 24 VIII 2021 [dostęp: 22 VII 2021]: 〈https://nato.int/cps/natohq/topics_132726.htm〉.

Relations with Azerbaijan, NATO, [dostęp 28 VI 2021]: <https:/www.nato.int/cps/ en/natohq/topics_49111.htm>.

Soszyn R., Hajiyev H., Przyjaźnimy się jednocześnie z Rosją i NATO, „Rzeczpospolita” [online], 10 II 2020 [dostęp: 22 VI 2021]. 